\title{
Antimicrobial, Antioxidant and Cytotoxic Activities of Gomphrena globosa (L.)
}

\author{
Md. Hamiduzzaman and A.T.M. Zafrul Azam
}

Department of Pharmaceutical Chemistry, Faculty of Pharmacy, University of Dhaka, Dhaka, Bangladesh

The plant Gomphrena globosa grows well in different parts of Bangladesh and used traditionally for many medicinal purposes. To verify the traditional uses the crude methanol extract and its hexane, carbon tetrachloride, chloroform and aqueous soluble fractions were subjected to antimicrobial, antioxidant and brine shrimp lethality bioassays. Among all extractives the hexane soluble fraction exhibited the highest antioxidant activity having $\mathrm{IC}_{50}$ value $13.17 \pm 0.308 \mu \mathrm{g} / \mathrm{ml}$ and the crude methanol extract showed significant antioxidant activity with $\mathrm{IC}_{50}$ value $20.35 \pm 0.360 \mu \mathrm{g} / \mathrm{ml}$. Additionally, the chloroform soluble materials revealed significant cytotoxicity with $\mathrm{LC}_{50}$ of $0.331 \pm 0.029 \mu \mathrm{g} / \mathrm{ml}$. On the other hand the carbon tetrachloride and chloroform soluble partitionates demonstrated mild to moderate antimicrobial activity (zone of inhibition, $8 \pm 0.208$ to $14 \pm 0.069 \mathrm{~mm}$ ).

Gomphrena globosa (L.) (Bengali name Botam phul, Family- Amaranthaceae) commonly known as glove amaranth is an annual branched herb which is cultivated as ornamental flowering herb in garden (Muller and Borsch, 2005). It is native to North-America, South-America, Myanmar, and India and grows well over Bangladesh. Amaranthaceae is a large family comprising around 10 sub families, 176 genera and 2400 species available all over the world (Judd et al., 2007; Kadereit et al., 2006). G. globosa is a folk remedy for oliguria, heat and empacho, hypertension (Yusuf et al., 2009), cough and diabetes (Arcanjo et al., 2011) and expectorant for animals (Asolkar et al., 1992). Since this plant has important medicinal properties, the present study has been undertaken and we, herein, report the antimicrobial, antioxidant and cytotoxic properties of G. globosa for the first time.

Whole plants of Gomphrena globosa (L.) were collected from Dhaka in November 2011. A voucher specimen (Accession no. 3557) for this collection has been deposited in University of Dhaka herbarium for future reference.

The powdered whole plant (800 g) of G. globosa was extracted with $3.5 \mathrm{~L}$ of methanol for 15 days and filtered through a cotton plug. The extract was then concentrated with a rotary evaporator. An aliquot $(5.0 \mathrm{~g})$ of the concentrated aqueous methanol extract was fractionated by the modified Kupchan partitioning protocol (Van Wagenen et al., 1993) and subsequent evaporation of solvents afforded hexane (1.80 g), carbon tetrachloride (1.55 g), chloroform (0.5 g) and aqueous soluble (0.75 g) materials. Partitionates obtained by this way were subjected to different biological screenings.

The antimicrobial activity of the extractives was determined by the disc diffusion method (Austin et al., 1999, Bauer et al., 1966) against 5 gram positive bacteria, 8 gram negative bacteria and 3 fungal strains (Table 1 ). The organisms were collected as pure cultures from the Institute of Nutrition and Food Sciences (INFS), University of Dhaka. The experiments were carried out in triplicate using ciprofloxacin and kanamycin as standard and the results have been shown as mean \pm SEM (standard error of mean).

For cytotoxicity screening, the hexane, carbon tetrachloride and chloroform soluble materials of crude methanol extract were separately dissolved in DMSO (Meyer et al., 1982; Persoone et al., 1980). The test samples were then applied against Artemia salina in a 1day in vitro assay. The experiments were carried out in triplicate using vincristine sulphate as standard and the results have been shown as mean \pm SEM (standard error of mean).

The antioxidant activity (free radical scavenging activity) of the extracts on the stable radical 1, 1-diphenyl2-picrylhydrazyl (DPPH) was determined by following standard protocol developed by Brand-Williams (Wichi,

Correspondence to: A.T.M. Zafrul Azam, E-mail address: zafrulazam@du.ac.bd 
1988; Auddy et al., 2003). Then \% inhibitions were plotted against respective concentrations used and from the graph $\mathrm{IC}_{50}$ was calculated by using tert-butyl-1hydroxyl toluene (BHT), a potential antioxidant as positive control. The experiments were carried out in triplicate and the results have been shown as mean \pm SEM (standard error of mean).

The primary data obtained from the experiments were manipulated as the source of responses. For each of the extracts, three samples were prepared for each of the bioassay. Data were expressed as mean \pm SEM (standard error of mean). Statistical differences between extract activities were determined using ANOVA followed by Least Significant Difference (LSD) testing. Differences were considered statistically significant when $\mathrm{p}<0.5$.

Different partitionates of methanol extract of G. globosa were tested for antibacterial and antifungal activities against a number of gram positive and gram negative bacteria as well as some fungi. Among all the partitionates, the carbon tetrachloride and chloroform soluble fraction of the methanol extract exhibited mild to moderate antibacterial and antifungal activity (Table1).

Table1. Antimicrobial activity of $G$. globosa extractives at $400 \mu \mathrm{g} / \mathrm{ml}$ per disc

\begin{tabular}{|c|c|c|c|c|}
\hline \multirow[b]{2}{*}{ Test organisms } & \multicolumn{4}{|c|}{ Diameter of the zone of inhibition (mm) } \\
\hline & $\mathrm{CME}$ & CTSF & $\mathrm{CSF}$ & Ciprofloxacin \\
\hline \multicolumn{5}{|l|}{ Gram positive bacteria } \\
\hline Bacillus cereus & $7 \pm 0.48$ & $9 \pm 0.100$ & $11 \pm 0.233$ & $44 \pm 0.234$ \\
\hline B. megaterium & $6.5 \pm 0.23$ & $8 \pm 0.208$ & $10 \pm 0.345$ & $44 \pm 0.33$ \\
\hline B. subtilis & $6.8 \pm 0.55$ & $9 \pm 0.401$ & $11 \pm 0.221$ & $44 \pm 0.200$ \\
\hline Staphylococcus aureus & $5 \pm 0.025$ & $9 \pm 0.115$ & $11 \pm 0.337$ & $44 \pm 0.370$ \\
\hline Sarcina lutea & $7.4 \pm 0.67$ & $10 \pm 0.260$ & $9 \pm 0.342$ & $44 \pm 0.33$ \\
\hline \multicolumn{5}{|l|}{ Gram negative bacteria } \\
\hline Escherichia coli & $5 \pm 0.43$ & $9 \pm 0$ & $12 \pm 0.273$ & $44 \pm 0$ \\
\hline Pseudomonas aeruginosa & $6 \pm 0.50$ & $9 \pm 0.045$ & $14 \pm 0.069$ & $44 \pm 0.127$ \\
\hline Salmonella typhi & $5.5 \pm 0.56$ & $8 \pm 0.076$ & $10 \pm 0.180$ & $44 \pm 0.100$ \\
\hline S. paratyphi & $7.6 \pm 0.098$ & $9 \pm 0.197$ & $11 \pm 0.120$ & $44 \pm 0.402$ \\
\hline Shigella boydii & $7.4 \pm 0.65$ & $10 \pm 0.208$ & $9 \pm 0$ & $44 \pm 0$ \\
\hline Sh. dysenteriae & $5.8 \pm 0.47$ & $9 \pm 0.445$ & $11 \pm 0.227$ & $44 \pm 0.450$ \\
\hline Vibrio mimicus & $7 \pm 0.32$ & $11 \pm 0.09$ & $9 \pm 0$ & $44 \pm 0.05$ \\
\hline Vibrio parahaemolyticus & $5 \pm 0.25$ & $9 \pm 0$ & $12 \pm 0.443$ & $44 \pm 0$ \\
\hline Fungi & & & & Kanamycin \\
\hline Candida albicans & $7 \pm 0.40$ & $9 \pm 0.173$ & $13 \pm 0.34$ & $25 \pm 0.167$ \\
\hline Aspergillus niger & $6.5 \pm 0.45$ & $10 \pm 0.167$ & $11 \pm 0.260$ & $25 \pm 0.33$ \\
\hline Saccharomyces cerevisiae & $6 \pm 0.43$ & $9 \pm 0.303$ & $8 \pm 0$ & $25 \pm 0$ \\
\hline
\end{tabular}

$\mathrm{CME}=$ Crude methanol extract; $\mathrm{CTSF}=$ Carbon tetrachloride soluble fraction; $\mathrm{CSF}=$ Chloroform soluble fraction

Table 2 shows the results of the brine shrimp lethality assay after $24 \mathrm{hr}$ exposure to the samples and the positive control vincristine sulfate. The positive control, compared with the negative control (DMSO) was lethal, depicting significant mortality to the shrimp.

The median lethal concentration $\left(\mathrm{LC}_{50}\right)$ of the test samples after $24 \mathrm{hr}$ was obtained by a plot of percentage of the shrimps killed against the logarithm of the sample concentration (toxicant concentration) and the best-fit line was obtained from the graph by means of regression analysis. Among all the fractions of crude methanol extract of Gomphrena globosa (L.), the chloroform soluble fraction exhibited highest lethality having $\mathrm{LC}_{50}$ value $(0.331 \pm 0.029) \mu \mathrm{g} / \mathrm{ml}$.
Table 2. Results of cytotoxicity screening of G. globosa

\begin{tabular}{llll}
\hline $\begin{array}{l}\text { Test } \\
\text { Samples }\end{array}$ & Regression line & $\mathrm{R}^{2}$ & $\mathrm{LC}_{50}(\mu \mathrm{g} / \mathrm{ml})$ \\
\hline CTSF & $\mathrm{Y}=42.28 \mathrm{x}-0.739$ & 0.957 & $15.851 \pm 0.148$ \\
CSF & $\mathrm{Y}=18.52 \mathrm{x}+58.89$ & 0.929 & $0.331 \pm 0.029$ \\
VS & $\mathrm{Y}=30.8 \mathrm{x}+60.64$ & 0.972 & $0.451 \pm 0.0207$ \\
\hline
\end{tabular}

VS= Vincristine sulfate, CTSF $=$ Carbon tetrachloride soluble fraction, $\mathrm{CSF}=$ Chloroform soluble fraction, $\mathrm{LC}_{50}(\mu \mathrm{g} / \mathrm{ml})$ values of different fractions are expressed as mean \pm SEM ( $n=3)$; SEM: standard error of mean

Table 3 shows that among the entire fractions of $G$. globosa, the crude methanol extract exhibited significant and its hexane soluble fraction showed highest free radical scavenging activity having IC $_{50}$ values $(20.35 \pm 0.360)$ $\mu \mathrm{g} / \mathrm{ml}$ and $(13.17 \pm 0.308) \mu \mathrm{g} / \mathrm{ml}$ respectively. 
Table 3. $\mathrm{IC}_{50}$ values of standard and partitionates of $G$. globosa in DPPH assay

\begin{tabular}{lc}
\hline Sample & IC $_{50}(\mu \mathrm{g} / \mathrm{ml})$ \\
\hline CME & $20.35 \pm 0.360$ \\
NHSF & $13.17 \pm 0.308$ \\
BHT & $20.39 \pm 0.245$ \\
\hline
\end{tabular}

$\mathrm{CME}=$ crude methanolic extract, NHSF=n-Hexane soluble fraction, $\mathrm{BHT}=$ tert-butyl-1-hydroxytoluene

On the basis of the above biological screenings and folk medicinal uses it can be concluded that this plant has significant medicinal properties. It is also clearly evident from the above findings that the whole plant of G. globosa has high antioxidant potential and significant cytotoxic activities. Therefore, the plant is a good candidate for further studies to isolate the bioactive principles.

\section{References}

Arcanjo, D.D.R., de Albuquerque, A.C.M., Neto, B.N., Silva, N.C.B.S, and Moita, M.M. 2011. Phytochemical screening and evaluation of cytotoxic, antimicrobial and cardiovascular effects of Gomphrena globosa L ethanolic extraction. J. Med. Plants Res., 5, 2006-2010.

Asolkar, L.V., Kakkar, K.K. and Chakre, O.J. 1992. Second Supplement to Glossary of Indian Medicinal Plants with Active Principles. Part-1 (A-K), CSIR, New Delhi.

Auddy, B., Ferreira, F., Blasina, L., Lafon, F., Arredondo, F., Dajas, R. and Tripathi, P.C. 2003. Screening of antioxidant activity of three Indian medicinal plants, traditionally used for the management of neurodegenerative diseases. J. Ethno pharmacol., 83, 131-138.

Austin, D. J., Kristinsson, K. G. and Anderson, R. M. 1999. The relationship between the volume of antimicrobial consumption in human communities and the frequency of resistance. Proc. Natl. Acad. Sci. USA, 96, 1152-1156.
Bauer, A.W., Kirby, W.M.M., Sheriss, J.C. and Turck, M., 1966. Antibiotic susceptibility testing by standardized single disc diffusion method. Am. J. Clin. Path.., 45, 493-496.

Judd, W.S., Campbell, C.S., Kellogg, E.A., Stevens, P.F., Michael, J. and Donoghue, M.J., 2007. Plant Systematics: A Phylogenetic Approach, $3^{\text {rd }}$ edn, Sinauer Associates, Inc.

Kadereit, G., Hohmann, S. and Kadereit, J.W., 2006. A synopsis of Chenopodiaceaesubfam.Betoideae and notes on the taxonomy of Beta. Willdenowia - Annals of the Botanic Garden and Botanical Museum Berlin-Dahlem, 36, 9-19.

Meyer, B.N., Ferringni, N.R., Puam, J.E., Lacobsen, L.B., Nichols, D.E., 1982. The use of biological assays to evaluate botanicals. Drug Info. J., 31, 516-554.

Muller, K. and Borsch, T., 2005. Phylogenetics of Amaranthaceae using matK/trnK sequence data - evidence from parsimony, likelihood and Bayesian approaches. An Missouri Bot. Garden, 92, 66-102.

Persoone, G., Sorgeloos, P., Roels, O. and Jaspers, E., (editors). 1980. The brine shrimp. Proceedings of the international symposium on the brine shrimp Artemia salina 1979; Texas, USA. Belgium: Universa Press; 1980.

Pieroni, A., Janiak, V., Dürr, C.M., Lüdeke, S., Trachsel, E. and Heinrich, M., 2002. In vitro antioxidant activity of noncultivated vegetables of ethnic Albanians in Southern Italy. Phytother. Res., 16, 467-473.

Van Wagenen, B.C., Larsen, R., Cardellina, J.H., II, Ran dazzo, D., Lidert, Z.C. and Swithenbank, C., 1993. Ulosantoin, a potent insecticide from the sponge Ulosaruetzleri. J. Org. Chem., 58, 335-337.

Wichi, H.P., 1988. Enhanced tumor development by butylated hydroxyanisole (BHA) from the proseceretive of effects of forestomach and oesophagealsqumous epithelium. Food Chem. Toxicol., 26, 717-723.

Yusuf, A.A., Iwuafor, E.N.O., Abaidoo, R.C., Olufajo, O.O. and Sanginga, N., 2009. Grain legume rotation benefits to maize in the northern Guinea savanna of Nigeria: Fixed-nitrogen vs. other rotation effects. Nutr. Cycl. Agroecosyst., 84, 129-139. 